\title{
Monosodium glutamate affects cognitive functions in male albino rats
}

\author{
Wafaa M. Abdel Moneim', Heba A. Yassa ${ }^{1 *}$, Rania A. Makboul ${ }^{2}$ and Nada A. Mohamed ${ }^{1}$
}

\begin{abstract}
Background: Monosodium Glutamate is a silent toxin in our food, especially our kids' food. Some of the products in the market contain MSG in a level exceed the European limit.

Method: Sixty male albino rats divided into three groups, control group, and treated groups, the first with a low dose of MSG (1/20 LD50) and the second with a high dose of MSG (1/10 LD50). All animals examined for cognitive function, serotonin level. The second part in this study, examination of some commercial food for the presence of MSG and its level by HPLC.

Results: MSG affected the cognitive function of treated rats in small and high doses of MSG. The weight of the animals in treated group with a high dose of MSG was significantly increased in comparison with the control group. Also, the cognitive function of the rats administered MSG affected significantly either in low dose and in high dose. Some of the studied commercial food in the market like Kapsa and Indomi contains a higher level of MSG more than the European limit.

Conclusion: MSG has many dangerous effects on health especially kids, so it is so necessary to declare its presence or
\end{abstract} absence and level on the labels of the products.

Keywords: Monosodium glutamate, Cognitive functions, Serotonin level

\section{Background}

Monosodium Glutamate (MSG) has a flavor-enhancing effect in our foods. When it is added to foods, it addes a flavoring function similar to naturally occurring free glutamate (International Food Information Council Foundation IFICF, 2001). It is used to enhance the natural flavors of meats, poultry, seafood, snacks, soups and stews (International Food Information Council Foundation IFICF, 2001). According to the inquiry by the governments of Australia and New Zealand in 2003, Chinese restaurant meal contains between 10 and $1500 \mathrm{mg}$ of MSG per $100 \mathrm{~g}$. A condensed soup typically contains between 0 and $480 \mathrm{mg}$ and packaged sauces or seasonings contain 20 to $1900 \mathrm{mg}$ (Freeman, 2006).

The consumption of MSG has increased all over the world in recent years with an average daily intake from foods reported to be about up to $1 \mathrm{~g}$ in Europe, $4 \mathrm{~g}$ in Asian countries and $10 \mathrm{~g}$ in Germany (Park et al., 2014). MSG

\footnotetext{
*Correspondence: Hebayassa@aun.edu.eg; heba612@hotmail.com ${ }^{1}$ Forensic Medicine and Clinical Toxicology Department, Faculty of Medicine Assiut University, Asyut, Egypt

Full list of author information is available at the end of the article
}

may be present in packaged foods without appearing on the label (Alalwani, 2014).

Many types of food contains MSG for example Frozen dinners and processed meat such as; bacon, pastrami, pepperoni, sausages, luncheon meats, smoked meat products, hamburger, cold cuts and salami. Sauces and dressing such as; ketchup, mayonnaise, barbecue sauce, salad dressing, soy sauce and mustard. Soup bases such as; bouillon cubes and granulated powders. Flavored snacks such as potato chips. Seasoning, spices, gelatin containing substance and bodybuilding protein powder (Anglesey, 1997; Lavine, 2007; Populin et al., 2007). Also, Fast-food restaurants commonly use MSG to enhance the flavor of anything from chicken nuggets, burger, fried chicken to the seasoning used on some French fries (Lavine, 2007).

The use of MSG was linked to Chinese restaurant syndrome (CRS), which was firstly described in 1968, which is characterized by headache, throbbing of the head, dizziness, a feeling of facial pressure, tightness of the jaw, burning or tingling sensations over parts of the body, chest pain and back pain (Park et al., 2014). Also, 
MSG can precipitate an attack of migraine in susceptible individuals; this may occur through an allergic reaction or may be due to change in vascular tone (Millichap \& Yee, 2003).

Studies in suckling rodent pups showed severe bodily disturbances and marked obesity after sc injection or oral administration of MSG, some of those animal models presented fasting hyperinsulinemia, hyperleptinemia, adiposity and increase of plasma fatty acids and triacylglycerols (Seiva et al., 2012). The administration of MSG to newborn rats results in distinctive lesions in hypothalamic arcuate nucleus neurons. The neuronal loss impairs insulin and leptin signaling and impacts energy balance as well as pituitary and adrenal activity (Yin et al., 2013).These effects are mostly attributed to immaturity of blood brain barrier in those young animals (Boonnate et al., 2015).

Metabolic syndrome involves insulin resistance and pancreatic changes, a study in adult rats showed that daily MSG dietary consumption was associated with reduced pancreatic $\beta$-cell mass and enhanced hemorrhages and fibrosis, but did not affect glucose homeostasis, which suggests that high dietary MSG intake may exert a negative effect on the pancreas and thus have a role in the epidemics of metabolic syndrome (Boonnate et al., 2015). Here, with a mature BBB, the effect of MSG has a different mechanism; MSG-induced cytotoxicity was associated with increased oxidative stress and led to apoptosis and autophagy of pancreatic $\beta$ - cells (Di Cairano et al., 2011). It has been reported that MSG has neurotoxic effects resulting in brain cell damage, retinal degeneration, endocrine disorders and some pathological conditions such as, stroke, epilepsy, neuropathic pain, schizophrenia, anxiety, depression, Parkinson s disease, Alzheimer's disease, Huntington's chorea, and amyotrophic lateral sclerosis, cited in (Eweka et al., 2013). Also, MSG can cause anxiogenic- and depressive-like behaviors (Porsolt et al., 1979; Onishi \& Xavier, 2010; Quines et al., 2014). Some studies reveled that it can affect the cognitive function and learning ability (AbuTaweel et al., 2014),memory retrieval (Pilgrim et al., 2012; Summers et al., 2003).

The aim of this study is to investigate the following;

1. Effect of MSG on nervous system regarding the cognitive function in male albino rats by;

a. Testing their cognitive behavior in a rat maze

b. Measuring serotonin level in brain tissue

c. Histopathological examination of brain tissue regions that are reported to be responsible for cognitive activities.

2. Quantification of MSG in different food samples, consumed in Assiut city, by High performance liquid chromatography.

\section{Material and methods}

The present study was conducted in the period from the 1st of December 2015 to the 10th of April 2016. It has been designed to study the effect of MSG on nervous system regarding the cognitive function in male albino rats and to measure the quantities of MSG in different food samples, consumed in our country Egypt, by HPLC.

\section{Chemicals}

L-Glutamic acid monosodium salt (MSG); Phosphate buffer solution (PBS); Serotonin ELISA kit, Formaline 10\%, Materials of High performance liquid chromatography (HPLC): All solvents were of HPLC grade, Merck (Darmstadt, Germany). All other materials were of analytical grade. Double distilled water was used for preparing solutions. NBD-Cl (7-chloro-4-nitrobenzo-2-oxa-1,3-diazole) was purchased from Sigma Chemical Co. (St. Louis, MO).

\section{Treatment protocol}

Ethical consideration for animal use

Ethical approvement from the Ethical committee- Assiut university - Faculty of Medicine were taken. All procedures for animals followed the Helsinki guidelines in the care, use of animals and in samples taken (Touitou et al., 2006).

Animals Sixty male albino rats of age range from 5 to 6 weeks were used, obtained from the animal house, Faculty of Medicine, Assiut University. Their weights were between 45 and $70 \mathrm{~g}$ at the beginning of the study.

The rats randomly divided into three groups for subacute experimental study, as follow:

Control Group (Group I): Twenty male albino rats: was subdivided into two equal groups;

- $\mathrm{C}_{\mathbf{1}}$ (positive control) $(\boldsymbol{N}=\mathbf{1 0})$ each animal received $3 \mathrm{ml}$ of the distilled water orally by gavage for 30 days.

- $\mathbf{C}_{2}$ (negative control) which was the blank group $(\boldsymbol{N}=\mathbf{1 0})$ in which animals received nothing except normal feeding.

Group II: Twenty male albino rats received MSG at a dose of $1.66 \mathrm{~g} / \mathrm{kg} /$ day $\left(1 / 10 \mathrm{LD}_{50}\right)$ dissolved in distilled water given orally by gavage for 30 days.

The $\mathrm{LD}_{50}$ of MSG in rats is $15-18 \mathrm{~g} / \mathrm{kg}$ body weight according to (Walker \& Lupien, 2000).

Group III: Twenty rats received MSG at a dose of $0.83 \mathrm{~g} / \mathrm{kg}$ body weight/day $\left(1 / 20 \mathrm{LD}_{50}\right)$ dissolved in distilled water given orally by gavage for 30 days.

According to the ethics of the experimentation on animals, rats were housed in groups in clean capacious cages (5 per cage) under standard laboratory conditions including good aerated room with suitable temperature, maintained at good light, with alternating $12 \mathrm{~h}$ light and dark cycle. Standard rats' food and water were available. 
The animals were observed during all days of the experiment and the weight was monitored by weighing every week.

Testing some of the cognitive function After the exposure period for 1 month and according to (Abu-Taweel et al., 2014), the animals subjected to cognitive behavioral tests in the eight-arm radial maze. Two types of memory are assessed in this test: reference memory and working memory. Reference memory is assessed when the rats only visit the arms of the maze that contains the reward. Working memory is assessed when the rats enter each arm a single time (Tarragon et al., 2012) .

\section{Biochemical analysis}

Serotonin levels in animals brain tissue and serum were determined using rat Serotonin ELISA kits according to the instructions of the manufacturer. Reactions were assessed by measuring the optical density using an automated ELISA reader at $450 \mathrm{~nm}$ according to (SunRed Shanghai, 2015).

\section{Sample preparation for serotonin measurement}

\section{Tissue samples}

- Parts of forebrains from all groups were rapidly frozen with liquid nitrogen after adding Phosphate buffer solution (PH 7.2-7.4). Samples then were melted at $2-8{ }^{\circ} \mathrm{C}$.

- PBS Phosphate buffer solution (pH 7.4)added to samples then homogenized by tissue homogenizer, centrifuged for 20-min at the speed of 2000-3000 r.p.m. and the supernatant was used for assay.

\section{Serum samples}

- Blood samples were taken then left to coagulate at room temperature then centrifuged for 20-min at the speed of 2000-3000 r.p.m. and the supernatants were used for assay.

\section{Test principle}

- The kit uses a double-antibody sandwich enzymelinked immunosorbent assay (ELISA) to assay the Rat Serotonin Transporter (SERT) in samples.

\section{Quantification of MSG in food samples by HPLC}

Method of (Populin et al., 2007) modified by Drug Research Center, Assiut University.

\section{Chromatographic system}

The chromatographic system consisted of an Dionex UltiMate 3000 HPLC System (Thermo Scientific, England), which consisted of a HPG-3400SD solvent delivery pump, WPS-3000(T)SL analytical Autosampler and Dionex UltiMate-3000 RS fluorescence detector. The HPLC system control and data processing were performed by computer integration software (Thermo Scientific $^{\text {Tx }}$ Dionex $^{\mathrm{Tx}}$ Chromeleon $^{\mathrm{Tx}}$ 7.2 Chromatography Data System (CDS) software).

The separation was achieved using a Luna RP-C18 column $(250 \times 4.6 \mathrm{~mm}, 5 \mu \mathrm{m})$, (phenomenex, USA) protected with a guard column (Phenomenex, USA) fitted just before the inlet junction of the analytical column.

Mobile phase consisted of a mixture of acetonitrile: $30 \mathrm{mM}$ phosphate buffer (potassium di-hydrogen phosphate and di-potassium hydrogen phosphate, adjusted to $\mathrm{pH}$ 3.5) in a ratio of 50:50, $v / \mathrm{v}$. Mobile phase was filtered through a $0.2 \mathrm{~mm}$ membrane filter (Phenomenex, USA) using vacuum filtration unit (Phenomenex, USA) and was degassed in an ultrasonic cleaner (Cole-Parmer, Chicago, IL, USA) and delivered at a flow rate of $1 \mathrm{~mL} / \mathrm{min}$. The injection sample volume was $20 \mu \mathrm{L}$. The fluorescence detector was set at $470 \mathrm{~nm}$ as the excitation wavelength and $530 \mathrm{~nm}$ as the emission wavelength. The chromatography was performed at room temperature.

\section{Food samples}

Three commercial food samples were purchased from supermarkets in Assiut city. Kabsa rice spices., Indomie noodles; chicken flavor and Potato chips; Kabab flavor.

\section{Preparation of solutions}

a) Standard and Sample Preparation

A stock solution of sodium glutamate $(200 \mu \mathrm{g} / \mathrm{ml})$ was prepared in water. The working standard solutions were prepared by diluting the stock solutions with water. The six calibration standards of sodium glutamate (final concentrations: $10,25,50,100,150$ and $200 \mu \mathrm{g} \mathrm{m}^{-1}$ ) were prepared independently. All solutions were stored at $4{ }^{\circ} \mathrm{C}$ until used.

One gram of each sample was quantitatively transferred to a $100 \mathrm{~mL}$ volumetric flask and dissolved in $50 \mathrm{~mL}$ water and completed to volume with the same solvent to produce a stock solution of $1 \%(w / v)$.

\section{b) NBD-Cl derivatizing reagent}

An accurately weighed amount of NBD-Cl $(25 \mathrm{mg})$ was quantitatively transferred to a $50 \mathrm{ml}$ volumetric flask and dissolved in $10 \mathrm{ml}$ methanol; the contents of the flask were diluted to volume with the same solvent to produce a stock solution of $0.05 \%(\mathrm{w} / \mathrm{v})$. The solution was freshly prepared daily and protected from light during use. 


\section{General Derivatization procedure}

Sodium glutamate standard solution $(1 \mathrm{ml})$ was transferred to a screw-cap reaction tube by using a micropipet. A volume of $1 \mathrm{ml}$ borate buffer, $\mathrm{pH}$ 8.6, and $100 \mu \mathrm{L}$ $\mathrm{NBD}-\mathrm{Cl}$ solution were added. The tube was capped, the contents were swirled, and the tube was left to stand in a thermostatically controlled water bath (Selecta, Spain) at $70{ }^{\circ} \mathrm{C}$ for $30 \mathrm{~min}$. The tube was cooled rapidly, and a volume of $100 \mu \mathrm{l} \mathrm{HCl}$ was added. A $20 \mu \mathrm{l}$ aliquot of the resulting solution was injected into the HPLC system.

\section{Calibration curve}

Sodium glutamate calibration standard solutions were derivatized and analyzed according to the described procedures. Three injections of each standard solution were made. Peak areas of varying amounts of sodium glutamate versus its corresponding concentrations were used to obtain the calibration curve.

\section{Statistical analysis}

Data were analyzed using SPSS software version 16. Differences among experimental groups were determined by One way ANOVA (analysis of variance) and Student $t$ test. Data was expressed as mean \pm Standard deviation (SD).

For all the data the $p$ value was considered; not significant if $>0.05$, significant if $<0.05$ and highly significant if $<0.001$.

\section{Results}

\section{Tabulations}

\section{Results of the first part (experimental study)}

There was no significant difference between negative (C1) and positive (C2) control groups in all parameters of the study. The results of groups II (high dose) \& III (low dose) were compared with the control group, Group I, (average of $\mathrm{C} 1$ and $\mathrm{C} 2$ ).

\section{Rats weight}

Table 1: Compares the mean body weight \pm SD in the three groups at the beginning and weekly throughout the study by using one way anova test. There is a statistically significant difference between three groups by the end of each week ( $p$. value $<0.05)$. Group III showed statistically significant increase in weight gain in Group III compared to the control groups $(p<0.05)$ in all the study periods. While GII showed a statistically significant increase in the mean $( \pm S D)$ of weight by the end of the first week $(p<0.05)$ compared to the control groups. However, in the second and third weeks the animals in Group II showed a statistically nonsignificant $(p>0.05)$ decrease in the mean of their body weight, then they started to gain weight in the fourth week. There was no significant difference in weight between group II and control groups in the second, third and fourth weeks $(p>0.05)$.

Figure 1 linear graph; showing the relationship between the mean weight in the three groups during the whole month.

\section{Assessment of some cognitive function}

Table 2 and Fig. 2: illustrate the cognitive function (reference and working memory) of the animals in the three groups assessed by the rat maze. Showing that the total time taken by the MSG exposed animals (Group II \& III) during the test period to enter the food containing arms was significantly increased $(p<0.001)$ compared to the control groups.

\section{Biochemical analysis}

Figure 3: illustrates the effect of MSG in high dose (Group II) and low dose (Group III) on the levels of the neurotransmitter; serotonin (5-HT), in tissue (forebrain) and serum of the male rats. Only the animals exposed to high dose (Group II) MSG were significantly affected $(p<0.05)$. Animals in Group III didn't show a statistically significant decrease in forebrain serotonin levels compared to control groups.

Table 3: Compares the mean serotonin level in forebrain tissue and serum in the three groups at the end of the study using one way ANOVA. There is a statistically significant difference between three groups, with $p$. value $\leq 0.001$ when comparing the mean serotonin level in forebrain tissue and

Table 1 Weight comparison between rats in the three groups using one way Anova test

\begin{tabular}{|c|c|c|c|c|c|}
\hline \multirow[t]{2}{*}{ Groups } & \multicolumn{5}{|l|}{ Mean weight \pm SD } \\
\hline & At-the beginning & 1st week & 2nd week & 3rd week & 4th week \\
\hline $\begin{array}{l}\text { Group I } \\
\text { (control) } \\
n=20\end{array}$ & $55 \pm 10$ & $60.91 \pm 13.1$ & $78.21 \pm 17.74$ & $94.74 \pm 27.73$ & $99.05 \pm 26.9$ \\
\hline $\begin{array}{l}\text { Group II } \\
\text { (high dose) } \\
\mathrm{n}=20\end{array}$ & $55 \pm 10$ & $86.17 \pm 15.19$ & $83.33 \pm 16.54$ & $80.66 \pm 17.5$ & $104.83 \pm 4.3$ \\
\hline $\begin{array}{l}\text { Group III } \\
\text { (low dose) } \\
\mathrm{n}=20\end{array}$ & $55 \pm 10$ & $81.17 \pm 8.63$ & $102.08 \pm 15.33$ & $127.67 \pm 20.15$ & $140.33 \pm 20$ \\
\hline$p$ value & & $0.007^{*}$ & $0.059^{*}$ & $0.007^{*}$ & $0.005^{*}$ \\
\hline
\end{tabular}

Values in each column followed by * are significantly different $(P \leq 0.05)$, and that followed by ** are highly significantly different $(P \leq 0.001)$ 


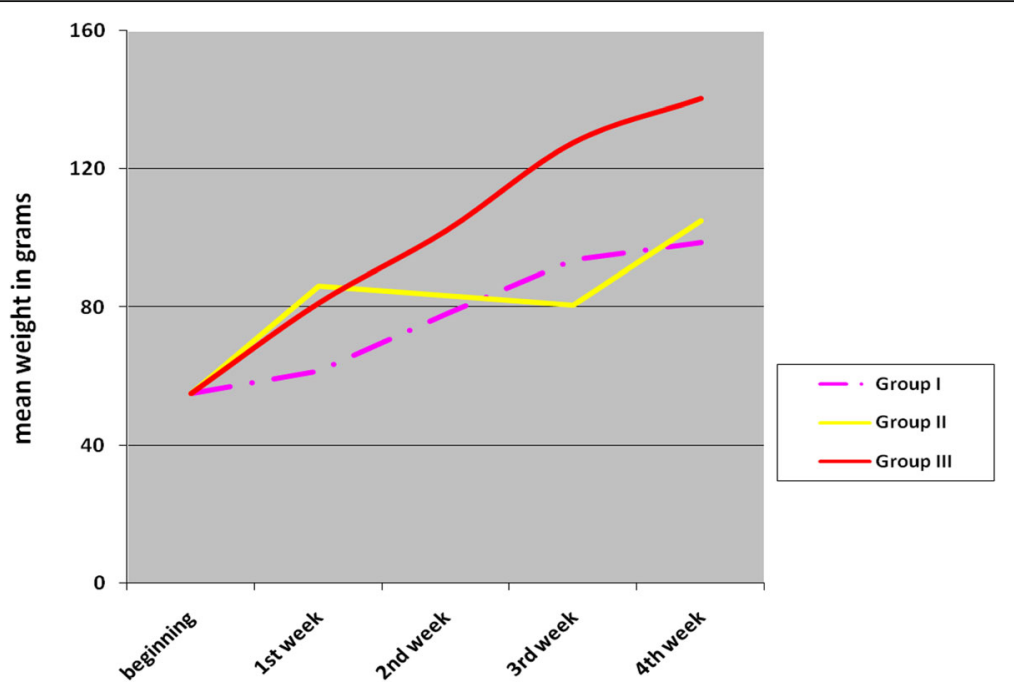

Fig. 1 Linear graph showing the relation between weight gain in rats treated with MSG for one month; Group II (high dose), Group III (low dose) and control groups

$p$. value $\leq 0.05$ when comparing the mean serotonin level in serum.

\section{Results of the second part}

This part of the study was performed to measure the quantity of monosodium glutamate in various food stuff and was conducted at Drug Research Center, Assiut University.

Figure 4: shows the calibration curve of monosodium glutamate obtained by plotting the final concentrations versus the peak areas of varying amounts of sodium glutamate .

Table 4 and Fig. 5: Illustrate the different concentrations of MSG in various food samples, the highest concentration (7.34\%) was found in Indomie, instant noodles chicken flavour, followed by potato chips Kabab flavour (2.1\%) and lastly the kabsa rice speices (1.36\%). It is important to note that the instant noodles and potato chips are ready to eat products with no further dilution of the estimated levels of MSG is expected before eating. This is not the case with rice spices where the MSG level is expected to be diluted about 10 times after cooking.

Table 2 The mean time taken by rats in each group in the rat maze to reach food in the maze arms using Student t test

\begin{tabular}{llll}
\hline Groups & $\begin{array}{l}\text { Group I } \\
\text { (Control) } \\
n=20\end{array}$ & $\begin{array}{l}\text { Group II } \\
\text { (High dose) } \\
n=20\end{array}$ & $\begin{array}{l}\text { Group III } \\
\text { (Low dose) } \\
n=20\end{array}$ \\
\hline $\begin{array}{l}\text { Mean time } \pm \text { SD } \\
\text { (in sec) }\end{array}$ & $14 \pm 1.67$ & $46.33 \pm 8.68$ & $23.5 \pm 2.35$ \\
t-test & & 8.952 & 8.077 \\
$p$-value & & $<0.001^{* *}$ & $<0.001^{* *}$ \\
\hline
\end{tabular}

Values in each column followed by * are significantly different $(P \leq 0.05)$, and that followed by ${ }^{* *}$ are highly significantly different $(P \leq 0.001)$

\section{Discussion}

Monosodium Glutamate (MSG) is one of the world's most extensively used food additives which is ingested as part of commercially processed foods (Husarova \& Ostatnikova, 2013).

In 1958 the U.S. Food and Drug Administration (FDA) designated MSG as a Generally Recognized As Safe (GRAS) ingredient, along with many other common food ingredients such as salt, vinegar and baking powder (International Food Information Council Foundation IFICF, 2001).

The glutamate industry often uses flavors in ingredients labeled "flavor," or "flavoring," (this preceded by the word "natural"). They use "reaction flavors" as "clean label" alternatives to the use of "monosodium glutamate". The consumers rarely know that "Clean label" can include MSG (Truth in Labeling, 2007).

The young children are usually at risk from MSG. Their blood brain barrier is not fully developed; and cannot protect against toxins. In addition, glutamic acid can penetrate the placental barrier. Companies use glutamic acid because it is cheap, and since it is neurotoxic, manufacturers continue to go on using it and do not want the public to know that. (NOHA, 2008).

In the current study, rats of group II (high dose) showed a significant increase in their body weights compared to the control group (Group I) in the first week of the study. This was followed by reduction in body weight in the second and third weeks followed by another increase in their weight in the last week. However, there was no significant difference in weight between group II and control by the end of the study $(p>0.05)$. The reduction in body weight that was noted in the second and third week agrees with other studies that also reported reduction in body weight 


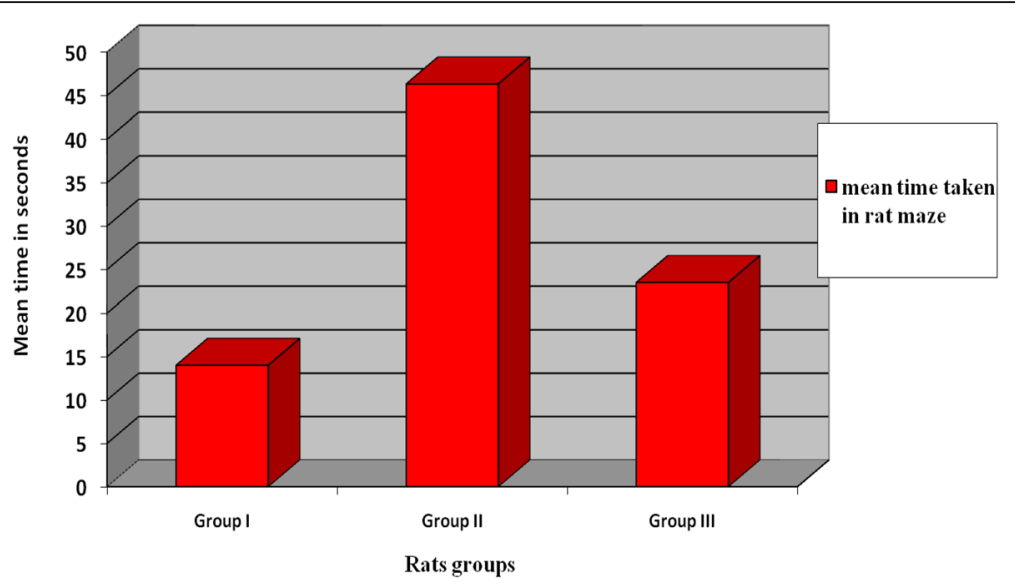

Fig. 2 The mean time taken by rats in each group in the rat maze to reach food in the maze arms

gain in animals treated with MSG (). The increase in weight in the last week can be attributed to the urinary retention (full bladder was noted upon dissecting all the animas of this group (Group II).

Rats in group III (low dose) showed a significant increase in body weight compared to control group $(p<0.05)$. This is concordant with Alalwani, 2014 (Alalwani, 2014) who reported a significant weight gain in MSG treated rats (single daily dose 30 or $60 \mathrm{mg} / \mathrm{kg}$ intra-peritoneal injection for 2 months). Another supporting study reported that MSG treated rats (subcutaneous injection of $4 \mathrm{~g}$ MSG/ $\mathrm{kg}$ body weight/day] presented higher body weights than the control rats, despite the fact that treated rats were found to be hypophagic, presenting lower average daily food consumption (de Oliveira Lazarin et al.,
2011). The different effect of MSG on body weight might be due to the variations in dose regimen and perhaps to different periods or duration of exposure and the type or strain of the animals used in these studies. Although MSG could improve the palatability of foods by exerting a positive influence on the appetite center (Alalwani, 2014). Its main effect on body weight is by increasing mRNA expression of interleukin-6, tumor necrosis factor-alpha, resistin and leptin in visceral adipose tissue, it increased insulin, resistin and leptin levels in serum and it also impaired glucose tolerance. The ingested glutamate also exerts a local effect; its presence in gastrointestinal tract activate both the gastric and the celiac branches of the vagus nerve led to the activation of the insular cortex, limbic system, hypothalamus and nucleus tractus solitaries (Husarova \& Ostatnikova, 2013).

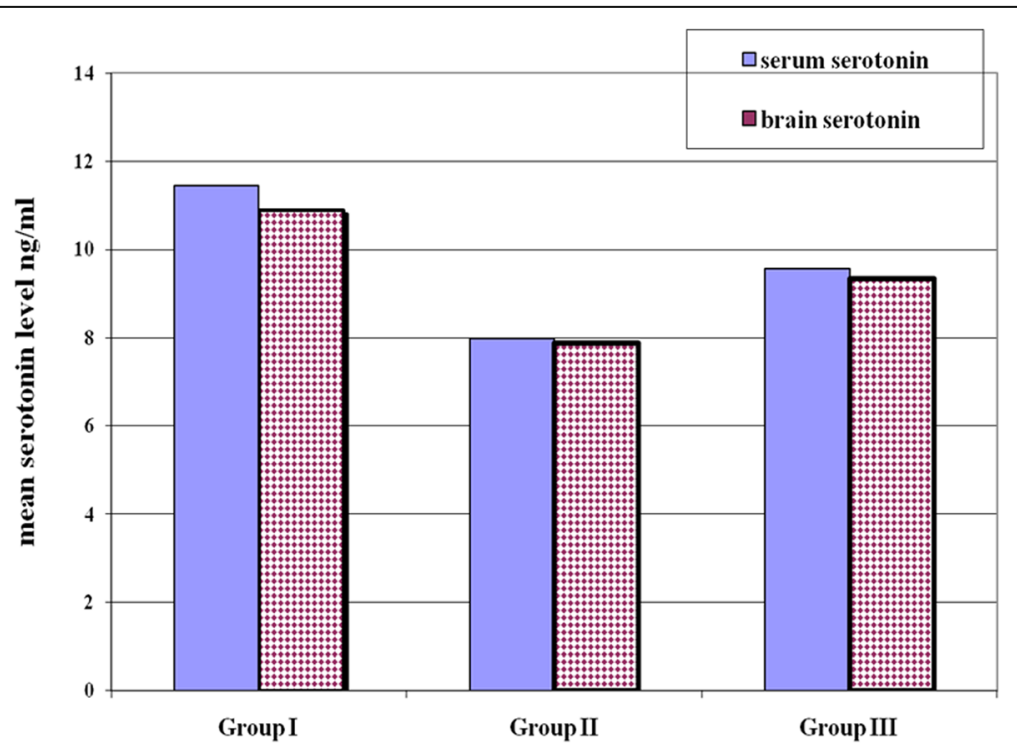

Fig. 3 Relation between mean serotonin levels in both forebrain and serum in all the study groups (Group I (C1 \& C2), Group II, Group III) 
Table 3 The level of serotonin (mean) in the forebrain and serum in the three groups after treatment using one way ANOVA

\begin{tabular}{lllll}
\hline Groups & $\begin{array}{l}\text { Group I } \\
\text { (Control) } \\
n=20\end{array}$ & $\begin{array}{l}\text { Group II } \\
\text { (High dose) } \\
n=20\end{array}$ & $\begin{array}{l}\text { Group III } \\
\text { (Low dose) } \\
n=20\end{array}$ \\
\hline Mean serotonin level in forebrain & 10.84 & 7.87 & 9.33 & $0.001^{* *}$ \\
Mean serotonin level in serum & 11.45 & 7.99 & 9.57 & $0.002^{*}$ \\
\hline
\end{tabular}

Values in each column followed by * are significantly different $(P \leq 0.05)$, and that followed by ${ }^{* *}$ are highly significantly different $(P \leq 0.001)$

Rats exposed to MSG (group II and III) in the present study showed decline in their learning capabilities and short memory as observed from their performance in the radial arm maze test. However the cognitive affection was much more obvious in the group receiving the higher dose. This finding is also supported by earlier studies (Ali et al., 2000; Olvera-Cortes et al., 2005; Porsolt et al., 1979). Onaolapo et al., 2017, concluded that in their study MSG associated with changes in open field activities, anxiety-related behaviors and brain glutamate/ glutamine levels; its ingestion leads to a stimulation of the brain reward system (Onaolapo et al., 2017).

The hippocampus in the forebrain plays a major role in controlling memory and regulating learning functions and thinking (Compton, 2004). Thus the decline in cognitive functions in animals exposed to MSG, as observed in the study, could be due to its neurotoxic effect on forebrain neurons including the hippocampus. Decline in the cognitive function can also be explained by alteration in brain neurotransmitters such as serotonin, dopamine, norepinephrine and acetylcholine (Husain \& Mehta, 2011).

Among different neurotransmitters, serotonergic alterations have been implicated in cognitive alterations, and low extracellular serotonin levels seem to be associated with impaired learning and memory consolidation (RamosRodriguez et al., 2013). In the present study only the animals exposed to high dose (Group II) MSG showed

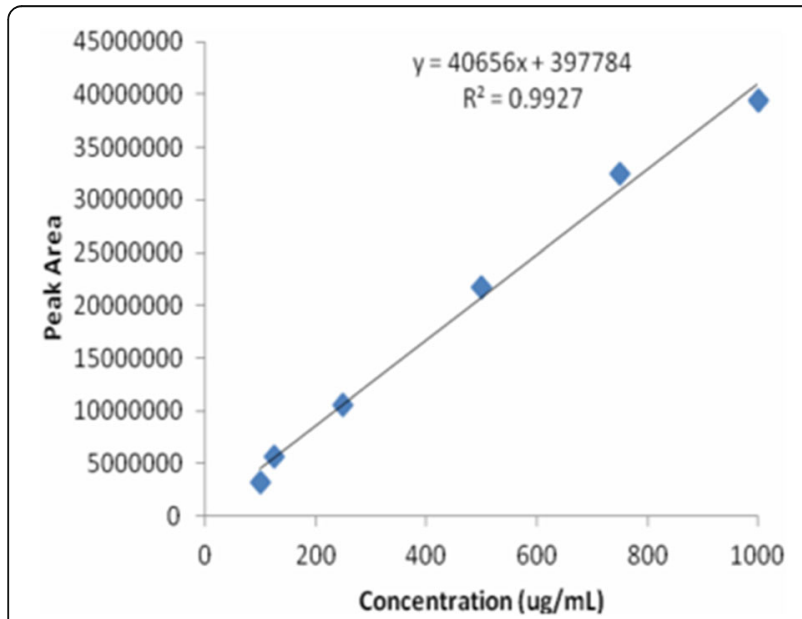

Fig. 4 Calibration curve of sodium glutamate obtained by the proposed HPLC method significant decrease $(p<0.05)$ in the levels of the neurotransmitter; serotonin in brain tissue as well as in serum. In support of the involvement of serotonergic mechanisms in MSG induced toxicity, a study has tested the MSG induced lethality (MSG; 6-10 g/kg, intra-peritoneal) in mice after adding drugs that depletes serotonin stores, this resulted in an increase in MSG-induced lethality (Kamei et al., 1991). In agreement with that, L-glutamic acid was reported to decrease serotonin synthesis, release in rat rostral and caudal rhombencephalic raphe cells culture and cause an increase in serotonin metabolism (Becquet et al., 1993). In another study; subcutaneous injection of MSG in newborn rats ( $4 \mathrm{~g} / \mathrm{kg} /$ day from the 1 st to 5 th postnatal day) results in an increase in the serotonin uptake in cerebral cortices (Quines et al., 2014).

On the other hand animals in Group III (low dose) didn't show a statistically significant decrease in forebrain serotonin levels compared to control group. The obtained data from Group III are in agreement with the study by (Dawson, 1983) where adult female mice were injected intraperitoneal with MSG (4 mg/g) and decapitated $30 \mathrm{~min}$ later, for measuring serotonin levels in their brain tissue, the results showed no significant alteration in the brain level of serotonin compared to control group. MSG administration (at a dose of $8 \mathrm{mg} / \mathrm{kg}$ body weight/day, dissolved in drinking water for 1 month) to mice also showed no significant alteration in the brain level of serotonin (Porsolt et al., 1979).

The optimal palatability concentration for MSG is between $0.2-0.8 \%(w / w)$ and its use tends to be selflimiting as over-use decreases its palatability (Löliger, 2000). The limit of added MSG to food products established by European Directive is $10 \mathrm{~g} / \mathrm{kg}$ (1\%) of product or prepared food (European Parliament and Council Directive, 1995).

Hashem et al., 2012 in their study agreed with this study about the dangerous effects of MSG on brain, they concluded that MSG has neurotoxic effect leading to degenerative changes in neurons and astrocytes in cerebellar cortex of albino rats (Hashem et al., 2012).

Also, Umukoro et al., 2015 proved that low dose of MSG given orally to mice did not produce significant impairment in the Y maze test but produce depressive like symptoms in the forced swim test at dose of $500 \mathrm{mg} / \mathrm{kg}$, and increased the levels of malondialdehyde (MDA) and decreased the level of glutathione (GSH) concentration in brain tissue (Umukoro et al., 2015). 
Table 4 The concentrations of Monosodium glutamate in food samples

\begin{tabular}{llll}
\hline Sample & Concentration & Equivalent to & Equivalent to \\
\hline Kabsa rice spices & $135.5 \mu \mathrm{g} / \mathrm{mL}$ & $13.55 \mathrm{~g} / \mathrm{Kg}$ & $1.355 \mathrm{~g} / 100 \mathrm{~g} \mathrm{(1.355 \% )}$ \\
$\begin{array}{l}\text { Indomie chicken } \\
\text { flavor }\end{array}$ & $733.5 \mu \mathrm{g} / \mathrm{mL}$ & $73.35 \mathrm{~g} / \mathrm{Kg}$ & $7.335 \mathrm{~g} / 100 \mathrm{~g}(7.335 \%)$ \\
$\begin{array}{l}\text { Potato chips; } \\
\text { Kabab flavor }\end{array}$ & $210.2 \mathrm{\mu g} / \mathrm{mL}$ & $21.02 \mathrm{~g} / \mathrm{Kg}$ & $2.102 \mathrm{~g} / 100 \mathrm{~g}(2.102 \%)$ \\
\hline
\end{tabular}

Prastiwi et al., 2015 found that the administration of MSG at a high dose of $3.5 \mathrm{mg} / \mathrm{g}$ body weight, but not at lower dosages, lead to significant decrease of motor coordination and the estimated total number of Purkinje cells of rats and significant correlation between motor coordination and the total number of Purkinje cells (Prastiwi et al., 2015).

This study was conducted to determine the monosodium glutamate content of selected food samples from market in Assiut city. Three different samples were selected these include; Kabsa rice spices, Indomie noodles; chicken flavor and Potato chips (Kabab flavor). Estimation of monosodium glutamate was carried out by modified HPLC (High Performance Liquid Chromatography). The results from laboratory analysis concluded that MSG was present, altogether in the three samples with the following values; $135.5 \mathrm{~g} / 100 \mathrm{~g}$ (1.35\%), $733.5 \mathrm{~g} / 100 \mathrm{~g}$ (7.33\%) and $210.2 \mathrm{~g} / 100 \mathrm{~g}(2.1 \%)$, respectively.
In case of spices, they are used to prepare $0.5-1.0 \mathrm{~kg}$ meat or rice and so the MSG was diluted 10 times (Lateef et al., 2012), so the estimated percent of MSG decreases to $0.135 \%$ in prepared food which lie within the optimal palatability concentration i.e. $0.2-0.8 \%$ as suggested by (Löliger, 2000). However in the other two samples; Indomie $(7.33 \%)$ \& potato chips $(2.1 \%)$, the estimated MSG levels exceed the allowable limit per serving (1\% of product or prepared food as stated by (European Parliament and Council Directive, 1995).

Another studies measured MSG levels in different food staffs using HPLC; in one of the reports, quantification of MSG in hamburgers commercially available in Argentine markets was $0.1-0.2 \%(w / w)$ (Rodriguez et al., 2003). In another study, a survey on free glutamic acid content in a variety of foods (broths, soups, sauces and salad dressings), with and without added monosodium glutamate (MSG), broths and soups with added MSG had free glutamic acid contents of $0.266-0.753 \%$. The highest amounts of free glutamic acid in foods with no added MSG were found in products containing hydrolyzed proteins 0.12\% (Populin et al., 2007). Lateef et al. (Lateef et al., 2012), used a modified HPLC method to quantify MSG in Pakistani spices using single organic mobile phase. The MSG concentration in different spice samples were was found in the range of $2.7-8.8 \%$. Another study was conducted to determine the monosodium glutamate content of selected traditional meat dishes. Six traditional

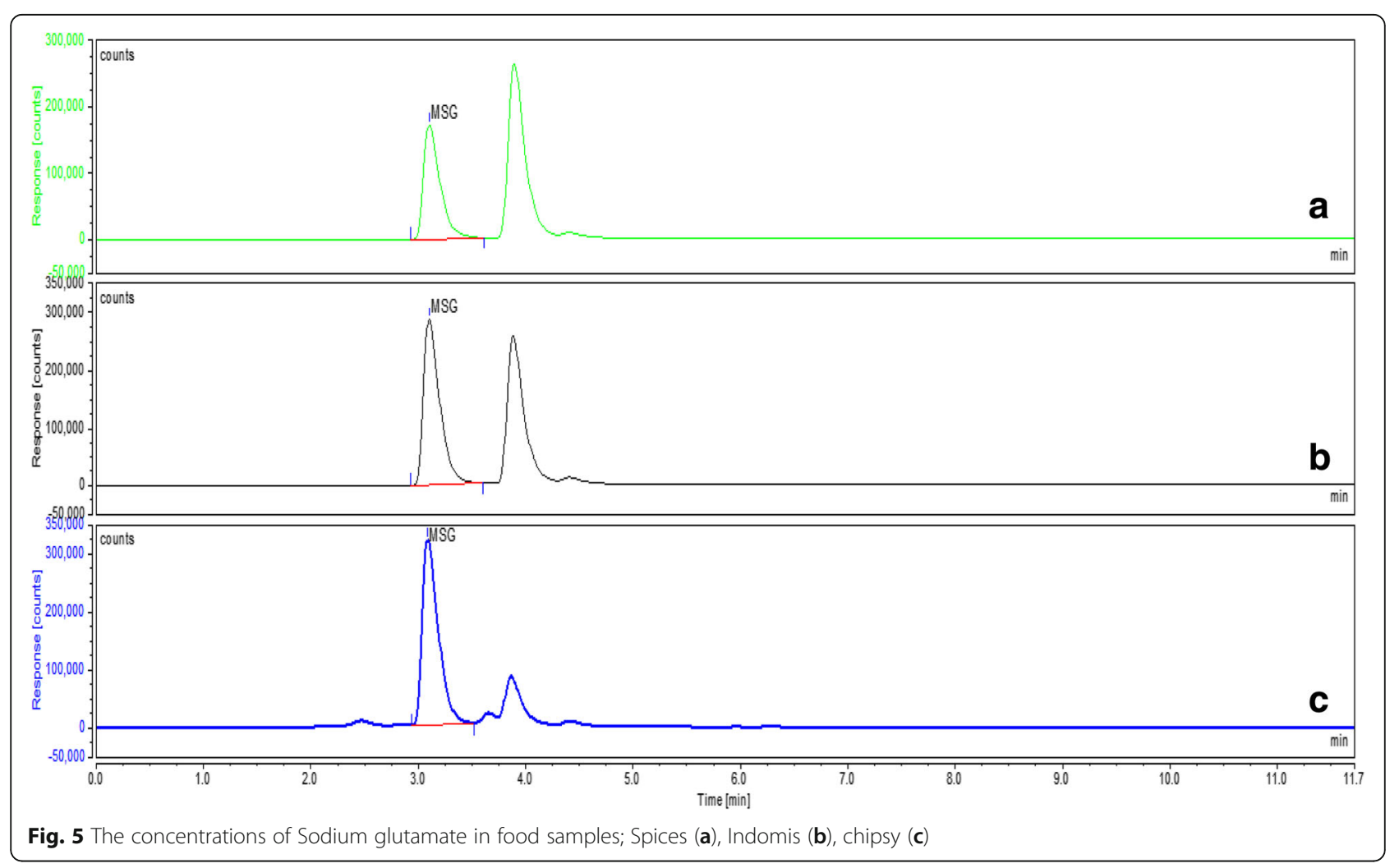


meat dishes were selected from five different restaurant of Lahore. The dishes included were chicken karahi, mutton qorma, chicken biryani, seekh kabbab, chicken tikkah, palak gosht, the estimated levels of MSG in all the meat dishes ranges from $0.2-0.8 \%$ (Mustafa et al., 2015).

\section{Conclusion}

Monosodium Glutamate is a silent toxin present in our food, especially our kids' food. It can cause decline in the cognitive functions and alternations in serum and brain serotonin levels. Also, it can cause degenerative changes in the brain of the male albino rats. At lower doses MSG caused a significant increase in weight; decline in cognitive function, but without alterations in serum or brain serotonin levels or pathological changes in the brain.

Some of the products in our market with added MSG exceeded the European limit of $10 \mathrm{~g} / \mathrm{kg}$ (1\%) of product. Other products may have MSG within the allowable limits, but one can ingest many of these products per day without paying attention to the total amount of MSG ingested. This confirms the necessity to declare on the label the percent of MSG present per product.

\section{Acknowledgements}

No applicable.

\section{Funding}

The research was funded for the lab test from the resarch funding unit in the faculty of Medicine, Assiut University.

\section{Availability of data and materials}

The datasets generated during and analyzed during the current study are available from the corresponding author on reasonable request.

\section{Authors' contributions}

WAM selected the subject, and revision of the research. HAY completed the statistics of the research, cognitive test and shared in writing. RMA shared in the lab test and writing. NAM shared in the lab test and writing. All authors read and approved the final manuscript.

\section{Authors' information}

Prof. Wafaa Abdel Moneim: Prof of forensic medicine and clinical toxicology, Assiut university, Faculty of Medicine, Egypt and Head of the department. Dr. Heba Atia Yassa: Ass. Prof of Forensic Medicine and Clinical Toxicology, Assiut University, Faculty of Medicine, Egypt.

Dr. Rania Makboul Ahmed: Lecturer of Pathology, Assiut University, Faculty of Medicine, Egypt.

Dr. Nada Awny Mohamed: Demonestrator of Forensic Medicine and Clinical Toxicology, Assiut University, Faculty of Medicine, Egypt.

\section{Ethics approval}

Ethical approval granted by the Ethical Committee Assiut University - Faculty of Medicine. All procedures for animals followed the Helsinki guidelines in the care, use of animals and in samples taken.

\section{Consent for publication}

All authors approve the publication in this form.

\section{Competing interests}

The authors declare that they have no competing interests.

\section{Publisher's Note}

Springer Nature remains neutral with regard to jurisdictional claims in published maps and institutional affiliations.

\section{Author details}

${ }^{1}$ Forensic Medicine and Clinical Toxicology Department, Faculty of Medicine Assiut University, Asyut, Egypt. ${ }^{2}$ Pathology Department, Faculty of Medicine Assiut University, Asyut, Egypt.

Received: 19 May 2017 Accepted: 12 January 2018

Published online: 26 January 2018

\section{References}

Abu-Taweel GM, Zyadah M, Ajarem JS, Ahmad M (2014) Cognitive and biochemical effects of monosodium glutamate and aspartame, administered individually and in combination in male albino mice. Neurotoxicol Teratol 42:60-67

Alalwani AD (2014) Monosodium glutamate induced testicular lesions in rats (histological study). Middle East Fertil Soc J 19:274-280

Ali MM, Bawari M, Misra U, Babu G (2000) Locomotor and learning deficits in adult rats exposed to monosodium-L-glutamate during early life. Neurosci Lett 284:57-60

Anglesey D (1997) Battling the MSG myth. Front Porch Productions, Kennewick, WA Becquet D, Hery M, Francois-Bellan A, Giraud P, Deprez P, Faudon M, Fache M, Hery F (1993) Glutamate, GABA, glycine and taurine modulate serotonin synthesis and release in rostral and caudal rhombencephalic raphe cells in primary cultures. Neurochem Int 23:269-283

Boonnate P, Waraasawapati S, Hipkaeo W, Pethlert S, Sharma A, Selmi C, Prasongwattana V, Cha'on U (2015) Monosodium glutamate dietary consumption decreases pancreatic $\beta$-cell mass in adult Wistar rats. PLoS One 10:e0131595

Compton DM (2004) Behavior strategy learning in rat: effects of lesions of the dorsal striatum or dorsal hippocampus. Behav Process 67:335-342

Dawson R (1983) Acute and long lasting neurochemical effects of monosodium glutamate administration to mice. Neuropharmacology 22:1417-1419

de Oliveira Lazarin M, Ishii-Iwamoto EL, Yamamoto NS, Constantin RP, Garcia RF, da Costa CEM, de Souza Vitoriano A, de Oliveira MC, Salgueiro-Pagadigorria CL (2011) Liver mitochondrial function and redox status in an experimental model of non-alcoholic fatty liver disease induced by monosodium Lglutamate in rats. Exp Mol Pathol 91:687-694

Di Cairano ES, Davalli AM, Perego L, Sala S, Sacchi VF, La Rosa S, Finzi G, Placidi C, Capella C, Conti P (2011) The glial glutamate transporter 1 (GLT1) is expressed by pancreatic $\beta$-cells and prevents glutamate-induced $\beta$-cell death. J Biol Chem 286:14007-14018

European Parliament and Council Directive (1995) No. 95/2/EC of 20 Feb 1995 on food additives other than colours and sweeteners. Official J L061:1-40

Eweka A, Igbigbi P, Ucheya R (2013) Histochemical studies of the effects of monosodium glutamate on the liver of adult wistar rats. Ann Med Health Sci Res 1:21-30

Freeman M (2006) Reconsidering the effects of monosodium glutamate: a literature review. J Am Acad Nurse Pract 18:482-486

Hashem HE, El-Din Safwat MD, Algaidi S (2012) The effect of monosodium glutamate on the cerebellar cortex of male albino rats and the protective role of vitamin C (histological and immunohistochemical study). J Mol Histol 43(2):179-186. https://doi.org/10.1007/s10735-011-9380-0

Husain M, Mehta MA (2011) Cognitive enhancement by drugs in health and disease. Trends Cogn Sci 15:28-36

Husarova V, Ostatnikova D (2013) Monosodium glutamate toxic effects and their implications for human intake: a review. JMED Res 2013:1-12

International Food Information Council Foundation IFICF (2001). www. foodinsight.org. Accessed June 2015

Kamei J, Igarashi H, Kasuya Y (1991) Modulation by serotonin of glutamateinduced lethality in mice. Res Commun Chem Pathol Pharmacol 74:167-184

Lateef M, Siddiqui K, Saleem M, Iqbal L (2012) Estimation of monosodium glutamate by modified HPLC method in various Pakistani spices formula. J Chem Soc Pak 34(1):39-42

Lavine A (2007) Monosodium glutamate (MSG) and food Labeling regulations. Food Drug $\sqcup$ 62:349

Löliger J (2000) Function and importance of glutamate for savory foods. J Nutr 130:915S-920S

Millichap JG, Yee MM (2003) The diet factor in pediatric and adolescent migraine. Pediatr Neurol 28:9-15

Mustafa S, Saleem Y, Hameed S (2015) Determination of monosodium glutamate content in selected traditional meat dishes. Int J Sci Eng Res 6:569-572 
(NOHA. (2008): Reactions to Free Glutamic Acid in Sensitive People. Available: http://www.nutrition\$health.org/nohanews/NNSp00_MSG.htm). Accessed June 2016

Olvera-Cortes E, Lopez-Vazquez M, Beas-Zarate C, Gonzalez-Burgos I (2005) Neonatal exposure to monosodium glutamate disrupts place learning ability in adult rats. Pharmacol Biochem Behav 82:247-251

Onaolapo OJ, Aremu OS, Onaolapo AY $(2017,2017)$ Monosodium glutamateassociated alterations in open field, anxiety-related and conditioned place preference behaviours in mice. Naunyn Schmiedeberg's Arch Pharmacol. https://doi.org/10.1007/s00210-017-1371-6

Onishi BK, Xavier GF (2010) Contextual, but not auditory, fear conditioning is disrupted by neurotoxic selective lesion of the basal nucleus of amygdala in rats. Neurobiol Learn Mem 93:165-174

Park E, Yu KH, Kim DK, Kim S, Sapkota K, Kim S-J, Kim CS, Chun HS (2014) Protective effects of $\mathrm{N}$-acetylcysteine against monosodium glutamateinduced astrocytic cell death. Food Chem Toxicol 67:1-9

Pilgrim LK, Murray JG, Donaldson DI (2012) Characterizing episodic memory retrieval: electrophysiological evidence for diminished familiarity following unitization. J Cogn Neurosci 24:1671-1681

Populin T, Moret S, Truant S, Conte LS (2007) A survey on the presence of free glutamic acid in foodstuffs, with and without added monosodium glutamate. Food Chem 104:1712-1717

Porsolt RD, Bertin A, Blavet N, Deniel M, Jalfre M (1979) Immobility induced by forced swimming in rats: effects of agents which modify central catecholamine and serotonin activity. Eur J Pharmacol 57:201-210

Prastiwi D, Djunaidi A, Partadiredja G (2015) High dosage of monosodium glutamate causes deficits of the motor coordination and the number of cerebellar Purkinje cells of rats. Hum Exp Toxicol 34(11)

Quines CB, Rosa SG, Da Rocha JT, Gai BM, Bortolatto CF, Duarte MMM, Nogueira CW (2014) Monosodium glutamate, a food additive, induces depressive-like and anxiogenic-like behaviors in young rats. Life Sci 107:27-31

Ramos-Rodriguez JJ, Molina-Gil S, Rey-Brea R, Berrocoso E, Garcia-Alloza M (2013) Specific serotonergic denervation affects tau pathology and cognition without altering senile plaques deposition in APP/PS1 mice. PLoS One 8:e79947

Rodriguez MS, Gonzalez ME, Centurion ME (2003) J Argent Chem Soc 91 (4/6):41-49

Seiva FR, Chuffa LGA, Braga CP, Amorim JPA, Fernandes AAH (2012) Quercetin ameliorates glucose and lipid metabolism and improves antioxidant status in postnatally monosodium glutamate-induced metabolic alterations. Food Chem Toxicol 50:3556-3561

Summers MJ, Crowe SF, Ng KT (2003) Memory retrieval in the day-old chick: a psychobiological approach. Neurosci Biobehav Rev 27:219-231

SunRed Shanghai, C. (2015). Rat(SERT)ELISA Kit. https://www.cusabio.com/ ELISA-Kit/Rat-serotonin-transporter5-HTTSERTELISA-Kit-104661.html. Accessed 16 Dec 2015

Tarragon E, Lopez L, Ros-Berna F, Yuste J, Ortiz-Cullera V, Martin E (2012) The radial arm maze (RAM) for the evaluation of working and reference memory deficits in the diurnal rodent. Octodondegus Proc Measuring Behav:98-100

Touitou Y, Smolensky MH, Portaluppi F (2006) Ethics, standards, and procedures of animal and human chronobiology research. Chronobiol Int 23(6):1083-1096

Truth in Labeling. 2007. What Is MSG. Available: http://www.truthinlabeling.org/III. What\%20is\%20MSG.htmL

Umukoro S, Oluwole G, Olamijowon H, Omogbiya A, Eduviere A (2015) Effect of monosodium glutamate on Behavioral phenotypes, biomarkers of oxidative stress in brain tissues and liver enzymes in mice. Biomed Life Sci 5(5):339-349. http://dx.doi.org/10.4236/wjns.2015.55033

Walker R, Lupien JR (2000) The safety evaluation of monosodium glutamate. J Nutr 130:1049S-1052S

Yin G-S, Lin S-D, Xu D-C, Sun R-Q, Lin K, Lin C-J (2013) Handle region peptide ameliorating insulin resistance but not $\beta$ cell functions in male rats neonatally treated with sodium L-glutamate. Int J Endocrino

\section{Submit your manuscript to a SpringerOpen ${ }^{\circ}$ journal and benefit from:}

- Convenient online submission

- Rigorous peer review

- Open access: articles freely available online

- High visibility within the field

- Retaining the copyright to your article

Submit your next manuscript at $\boldsymbol{\nabla}$ springeropen.com 